\title{
Nucleosome Core Particle
}

National Cancer Institute

\section{Source}

National Cancer Institute. Nucleosome Core Particle. NCI Thesaurus. Code C13811.

Nucleosome core particle consists of the 146 base pair highly protected DNA segment and its bound histone octamer (two of each histones $\mathrm{H} 2 \mathrm{~A}, \mathrm{H} 2 \mathrm{~B}, \mathrm{H} 3$ and $\mathrm{H} 4$ ).

Nucleosome core particle, linker DNA and histone $\mathrm{H} 1$ comprise one structural unit of chromatin, nucleosome. $(\mathrm{NCl})$ 